\title{
PENYELESAIAN SENGKETA TANAH PERUSAHAAN BADAN USAHA MILIK NEGARA (BUMN) PERKEBUNAN DI SUMATERA UTARA
}

\author{
Oleh: \\ Dr. Kusbianto, SH, M.Hum \\ Universitas Dharmawangsa Medan \\ Email: kusbianto yanto@yahoo.co.id
}

\begin{abstract}
ABSTRAK
Penyelesaian sengketa tanah antara PT.Perkebunan Nusantara di Sumatera Utara dengan masyarakat penggarap, pada kenyataannya sampai saat ini belum dapat diselesaikan dengan jelas dan tuntas. Kegagalan penyelesaian sengketa tanah perkebunan baik yang ditempuh dengan melalui proses pengadilan (litigasi) maupun dengan cara musyawarah di luar pengadilan (non-litigasi), ada beberapa sebab, yaitu : pertama, penyelesaian melalui pengadilan dirasakan kurang memenuhi rasa keadilan, anggapan para penggarap Pengadilan berpihak kepada perkebunan. kedua; penyelesaian sengketa dengan cara pendekatan non-litigasi dilakukan dengan cara pendekatan keamanan (security approach) berdampak jatuhnya korban jiwa dan harta benda, menimbulkan rasa permusuhan di kedua belah pihak semakin tajam. Perusahaan perkebunan dalam penyelesaian sengketa tanah garapan dengan bentuk suguh hati, yaitu memberi ganti rugi. Perlu di cari bentuk atau model penyelesaian sengketa yang dapat menyelesaikan sengketa dengan tuntas antara perusahaan dan penggarap.
\end{abstract}

Kata kunci : Sengketa tanah, perkebunan Negara.

\section{PENDAHULUAN}

Sejarah perkebunan-perkebunan di Sumatera Utara, dahulu Sumatera Timur sangat erat hubungannya dengan politik perdagangan bangsa Belanda yang ingin memperoleh hasil komoditi tembakau terbaik dari daerah asalnya, karena pada waktu itu perdagangan tembakau sangat menguntungkan di Eropa. Deli Maatschappij sebuah perusahaan perkebunan tembakau milik bangsa Belanda yang pertama didirikan di Sumatera Timur pada tahun 1869, dan mengalami sukses besar. Ekspansi perusahaan perkebunan di Sumatera Timur berkembang tidak saja dalam usaha perkebunan tembakau, tetapi diikuti dengan berdirinya perusahaanperusahaan perkebunan karet, teh, kelapa sawit dan serat di Pulau Raja, Asahan dan Labuhanan Batu.

Perkebunan besar yang dikelola Negara asal-muasalnya dari perusahaanperusahaan asing Belanda yang diambil alih Pemerintah Repubilk Indonesia dengan cara Nasionalisasi pada tahun 1958, berdasarkan Undang-Undang Nomor 86 Tahun 1958 (LN. 1958-162).

Kebijakan di bidang tanah yang bersifat populis pada era Orde Lama adalah dikeluarkannya Undang-undang Pokok Agraria 1960 (UU No. 5 Tahun 
1960). ${ }^{1}$ Undang-undang ini mendasarkan pada hukum adat yang telah disempurnakan sehingga segala bentuk hak-hak tanah di zaman Belanda dihapuskan dan diubah menjadi hak-hak yang diatur oleh UUPA. UUPA menetapkan pembatasan penguasaan tanah agar tidak merugikan kepentingan umum, melindungi hak-hak tanah perseorangan yang diletakkan dalam dimensi fungsional, yang berarti hak atas tanah mengacu pada kepentingan umum.

Kebijakan pertanahan kembali mengalami perubahan ketika terjadi pergantian pemerintahan.Pemerintah Orde Baru cenderung melakukan kebijakan pembangunan dengan ekonomi sebagai panglimanya. Hal ini menyebabkan adanya perubahan persepsi terhadap fungsi tanah sebagai salah satu sumber daya alam yang sangat unik sifatnya.Tanah dilihat sebagai sarana investasi dan alat akumulasi modal.Perubahan ini berlangsung sejalan dengan perubahan kebijakan pertanahan yaitu dari kebijakan yang memihak kepentingan rakyat ke kebijakan yang lebih memihak pada kepentingan kapitalis. UUPA tetap dipertahankan meskipun tidak lagi menjadi induk seluruh peraturan yang berlaku di bidang agraria. ${ }^{2}$ Sejumlah undang-undang lain

${ }^{1}$ Eddy Ruchiyat, op.cit., hal 43-61 dan lampiran; Noer Fauzi, op.cit., hal. 69-100.

${ }^{2}$ Noer Fauzi, op.cit., hal. 158. yang justru bertentangan dengan UUPA ditampilkan, misalnya UU No. 1 Tahun 1967 tentang Penanaman Modal Asing dan UU No. 5 tahun 1967 tentang Ketentuan Pokok Kehutanan yang memberikan kesempatan kepada berbagai kalangan untuk memperoleh Hak Pengusahaan Hutan (HPH) dan Hak Pemungutan Hasil Hutan (HPHH). Berlakunya undang-undang ini menyebabkan hak-hak masyarakat, misalnya hak-hak adat atas tanah atau hak ulayat menjadi terpinggirkan.Hak-hak mereka tergusur oleh kepentingan para pemilik modal. Pada periode ini konflik tidak lagi melibatkan petani kecil atau petani penggarap dengan tuan tanah melainkan antara pihak pemilik tanah (petani/rakyat) dengan pihak pemilik modal besar dan negara. Negara dapat bertindak sebagai fasilitator yang memberi dukungan terhadap pemilik modal besar dan bahkan negara itu sendiri, dengan mengatasnamakan pembangunan, merupakan pihak yang secara langsung bersengketa dengan rakyat. $^{3}$

Sengketa tanah pada era Orde Baru justru muncul dalam frekuensi yang lebih banyak dengan alasan yang berbeda. ${ }^{4}$

${ }^{3}$ Gunawan Wiradi, Reforma Agraria:Perjalanan yang Belum Berakhir (Yogyakarta: Insist, 2000), hal. 148.

4 Mubyarto, Tanah dan Tenaga Kerja Perkebunan: Kajian Sosial dan Ekonomi (Yogyakarta: Aditya Media, 1993), hal. 198. Isu dalam konflik pertanahan bermacam-macam, misalnya penggusuran Jurnal Ilmiah "Advokasi" Vol. 06. No. 01 Maret 2018 
Sengketa tanah perkebunan yang banyak terjadi, khususnya di daerah-daerah kantong perkebunan seperti di Jawa dan Sumatra, muncul karena adanya penetapan baru, perpanjangan, maupun pengalihan Hak Guna Usaha atas lahan perkebunan dan/atau bekas lahan perkebunan yang sudah digarap oleh rakyat. Wilayah sengketa juga semakin meluas, tidak hanya terjadi pada masyarakat pedesaan tetapi juga pada masyarakat perkotaan. Penggusuran rumah tinggal di berbagai kota besar misalnya, yang digunakan untuk keperluan para pemilik modal, pengembang perumahan-perumahan mewah, maupun sejumlah proyek milik pemerintah. UU No. 20 Tahun 1961 mengenai Pencabutan Hak-hak atas Tanah dan Benda-benda yang ada di atasnya ditafsirkan sedemikian rupa sehingga dalam praktek, untuk kepentingan umum atau bahkan untuk kepentingan swasta, pejabat setingkat gubernur atau bupati dapat melakukan pencabutan hak atas tanah. Penggusuran tanah milik rakyat dilakukan oleh pemerintah untuk kepentingan negara atas nama pembangunan, untuk kepentingan para pemilik modal, atau bahkan kepentingan individu yang mempunyai akses pada kekuasaan.

yang sewenag-wenang, masalah ganti rugi, masalah izin lokasi, masalah pemaksaan penanaman tanaman tertentu, pelecehan hak-hak adat dan lain-lain. Gunawan Wiradi, op.cit., 148.
Penggusuran tersebut biasanya dilakukan dengan ganti rugi yang tidak memadai yang jelas sangat tidak adil bagi pemilik tanah. Dalam UU No. 5 Tahun 1960 tentang Ketentuan Dasar Pokok-Pokok Agraria pada dasarnya dibedakan kepemilikan atas tanah antara subyek hak yakni antara warga Negara Indonesia dengan warga Negara Asing. Warga Negara Indonesia diberikan kemungkinan untuk mempunyai hak atas tanah sedangkan Warga Negara Asing dibatasi untuk mendapatkan hak atas tanah, hanya pada hak atas tanah tertentu saja, yakni hak atas tanah yang terbatas jangka waktunya, seperti Hak Pakai dan Hak Sewa. Pembatasan penguasaan tanah oleh orang asing tersebut mengambil prinsip dasar kepada pemilikan yang tumbuh pada hak ulayat. Dalam hak ulayat ditentukan bahwa orang luar (dalam arti diluar anggota persekutuan hukum adat) dibatasi untuk memiliki tanah dilingkungan persekutuan hukum tersebut.Berbeda ketentuan yang berlaku pada zaman penjajahan Hindia Belanda saat berlakunya BW, yang menetapkan bahwa setiap orang boleh saja memiliki hak atas tanah seperti hak eigendom, hak opstal dan hak erfpacht asalkan yang bersangkutan tunduk kepada BW tersebut. Bahkan kepemilikan tanah berdasarkan BW bersifat mutlak dan sacre artinya pemilik tanah dengan cara yang seluas mungkin dapat menikmati 
dan mempergunakannya, bahkan dengan sifat kemutlakannya maka hak itu keluar dari domein Negara sebagaimana diatur dalam domeinverklaring, yakni selain tidak dibuktikan dengan hak eigendom seseorang maka semua bidang tanah yang ada adalah domein Negara. ${ }^{5}$

Sesudah berlakunya UndangUndang Pokok Agraria Nomor 5 Tahun 1960, hukum tanah nasional yang berlaku adalah hukum tanah yang mengatur jenisjenis hak atas tanah dalam aspek perdata dan dalam aspek administrasi yang berisi politik pertanahan nasional yang semuanya itu bertujuan akhir pada penciptaan unifikasi hukum pertanahan di Indonesia.UUPA sebagai hukum agraria nasional disaneer dari hukum adat. ${ }^{6}$ Sebagai hukum tanah nasional, UUPA merupakan peraturan dasar dari peraturan pelaksanaan yang berkaitan dengan tanah, baik yang berupa undangundang maupun peraturan pemerintah.

\section{Sengketa Tanah Perkebunan Di PTPN}

Perusahaan Perkebunan adalah pelaku usaha perkebunan warganegara Indonesia atau badan hukum yang didirikan menurut hukum Indonesia dan berkedudukan di Indonesia yang mengelola usaha perkebuan dengan sekala tertentu (Undang-Undang No. 18

\footnotetext{
${ }^{5}$ Muhammad Yamin Lubis, 2013, Kepemilikan Properti Di Indonesia Termasuk Kepemilikan Rumah Oleh Orang Asing, Mandar Maju, Bandung, hal 3. ${ }^{6}$ Ibid.
}

Tahun 2004 tantang Perkebunan, Pasal 1 angka 6).

Badan Usaha Milik Negara, yang selanjutnya disebut BUMN, adalah badan usaha yang seluruh atau sebagian besar modalnya dimiliki oleh negara melalui penyertaan secara langsung yang berasal dari kekayaan negara yang dipisahkan. (Undang-Undanng No. 19 Tahun 2003 tentang Badan Usaha Milik Negara).

Perusahaan Perseroan yang selanjutnya disebut Persero, adalah BUMN yang berbentuk perseroan terbatas yang modalnya terbagi dalam saham yang seluruh atau paling sedikit 51 $\%$ (limapuluh satu persen) sahamnya dimiliki oleh Negara Republik Indonesia yang tujuan utamanya mengejar keuntungan (UU No. 19 Tahun 2003 tentang BUMN, Pasal 1 angka 2). BUMN Perkebunan memiliki doktrin Tri Darma Perkebunan yang berisikan penciptaan lapangan kerja, peningkatan penerimaan Negara, dan pelestarian lingkungan hidup. Saat ini di Propinsi Sumatera Utara terdapat tiga perusahaan perkebunan BUMN yakni PT. Perkebunan Nusantara (PTPN) Persero II, III dan IV.

Hak Guna Usaha (HGU) adalah salah satu jenis hak atas tanah yang diakui secara yuridis formal oleh Pasal 16 dan Pasal 28 s/d 34 Undang-Undang Pokok Agraria Nomor 5 Tahun 60 serta Peraturan Pemerintah Nomor 40 Tahun 
1996 Tentang Hak Guna Usaha, Hak Guna Bangunan Hak Pakai Atas Tanah. Bahwa pengertian HGU dari yang terkandung di dalam isi pasal-pasal tersebut diatas dapat disimpulkan hak untuk mengusahakan tanah yang dikuasai langsung oleh Negara dalam jangka waktu paling lama 35 tahun dan dapat diperpanjang 25 tahunyang digunakan untuk perusahaan pertanian, perkebunan, perikanan dan peternakan.

Yang dapat mempunyai HGU adalah Warga Negara Indonesia dan Badan Hukum yang didirikan menurut hukum Indonesia dan berkedudukan di Indonesia. HGU terbit karena berapa cara yaitu, karena penetapan pemerintah dan dapat juga karena ketentuan konversi, namun tidak dimungkinkan karena perjanjian. Guna kepastian hukum persyaratan pemberian HGU harus didaftarkan, demikian juga peralihan dan penghapusannya.

Ditinjau dari aspek hokum perdata secara substantive fungsi pendaftaran adalah memiliki momentum yang penting untuk melahirkan hak kebendaan.Dalam aspek hukum perdata ajektif, HGU yang sudah didaftarkan memiliki bukti yang kuat, terkecuali untuk HGU yang hapus karena jangka waktunya telah berakhir.

Dalam pengertian yang mutlak (absolute) pemegang HGU adalah pemegang hak dan yang memberikan hak adalah Negara. Apabila jangka waktu hak telah berakhir dan tidak diperpanjang maka hak dikembalikan kepada Negara. Hak dalam perspektif hukum positif diartikan sebagai kewenangan yang diberikan oleh peraturan perundangundangan kepada subjek hukum untuk melakukan sesuatu atau tidak melakukan sesuatu.

UUPA tidak ada melarang kepada pemegang HGU untuk mengalihkan kepada orang lain, tetapi di dalam Peraturan Pemerintah Nomor 40 Tahun 1996, larangan mengalihkan HGU kepada orang lain ditegaskan dengan pengecualian berdasarkan peraturan perundang-undangan. Larangan ini berlaku ketika jangka waktu HGU belum berakhir. Apabila HGU sudah berakhir dan tidak diperpanjang lagi, apakah pemegang HGU dibolehkan mengalihkan kepada pihak lain.

UUPA dan Peraturan Pemerintah Nomor 40 Tahun 1996 tidak memberikan jalan keluar yang tegas.Secara eksplisit sudah jelas bahwa hapusnya HGU membawa konsekwensi yuridis yaitu tanah tersebut menjadi tanah Negara. Bagi pemegang hak bila HGU tidak diperpanjang maka akan melahirkan 2 (dua) kewajiban, yaitu :

1. Membongkar bangunan-bangunan dan benda-benda yang ada diatasnya

2. Menyerahkan tanah dan tanaman yang ada diatas tanah bekas HGU tersebut 
kepada Negara dalam batas waktu yang ditetapkan oleh Menteri.

Dari kewajiban hukum yang pertama berarti bekas pemegang HGU masih memiliki hak atas bangunanbangunan dan benda-benda yang ada diatas tanah bekas HGU-nya.Hal ini sesuai dengan asas pemisahan horizontal yang dianut UUPA.Terhadap kewajiban hokum yang kedua adalah bekas pemegang HGU menyerahkan tanah HGU yang sudah berakhir kepada Negara dengan ketentuan diberikan batas waktu oleh Menteri. Menteri yang dimaksud adalah Menteri yang mengurusi bidang pertanahan, dalam hal ini Kepala Badan Pertanahan Nasional. Didalam UUPA dan Peraturan Pemerintah Nomor 40 Tahun 1996 tentang Hak Guna Usaha, Hak Guna Bangunan Dan Hak Pakai disebut bahwa salah satu yang dapat menjadi pemegang HGU adalah Badan Hukum yang didirikan menurut hokum Indonesia dan berkedudukan di Indonesia $^{7}$.

Kapitalisasi tanah dan sumber daya alam sesuatu yang sejatinya ingin dihapuskan oleh UUPA, hampir tidak pernah terjadi pada praktiknya pengakuan pemerintah terhadap hak-hak adat sangat jarang ditemukan atau hampir tidak

${ }^{7}$ Tan Kamelo, Peralihan Hak Atas Tanah Eks Hak Guna Usaha PTPN (Persero) Sebagai Badan Usaha Milik Negara Kepada Pihak Lain, Seminar Pengalihan Hak Atas Tanah Eks Hak Guna Usaha Di Sumatera Utara, Permasalahan Dan Solusinya, 2006, Fakultas Hukum USU pernah terjadi. Perampasan hak-hak masyarakat yang justru banyak dilakukan dengan dalih untuk melayani kepentingan pembangunan yang dijalankan oleh kaum pemodal baik dari dalam maupun luar negeri. 8 Reformasi Agraria yang dilakukan dengan diberlakukannya Undang-Undang Nomor 5 Tahun 1960 tentang Pokok-Pokok Agraria yang mengatur penguasaan dan kepemilikan tanah lebih adil, masih memberikan hak kepada perusahaan perkebunan melalui pemberian Hak Guna Usaha (HGU). Lahirnya Undang-Undang Nomor 1 Tahun 1967 tentang Penanaman Modal Asing dan Undang- Undang Nomor 6 Tahun 1968 tentang Penanaman Modal Dalam Negeri hal ini membuat usaha perkebunan oleh swasta asing dan nasional kembali bermunculan.

Semaraknya pertumbuhan perusahaan-perusahaan perkebunan pada puncaknya Indonesia menjadi salah satu Negara terbesar pengeksport crude palm oil (CPO) atau minyak sawit mentah, Sumatera Utara pengekspor terbesar selain daripada Riau. Keberhasilan perkebunan ini tidak dibarengi dengan peningkatan kesejahteraan bagi masyarakat di sekitar perkebunan.

Reformasi pada tahun 1998 dijadikan momentum masyarakat masuk ke areal perkebunan menduduki,

${ }^{8}$ Myrna Safitri, 2006, Simposium Agraria I, Medan, hal 1 . 
menyerobot tanah yang dikuasai dan diusahai perkebunan serta melakukan tuntutan dengan alasan penyelesaian tanah garapan pada masa orde baru tidak adil agar hak-hak petani penggarap dan hak masyarakat adat dikembalikan kepada rakyat (petani). Situasi dan kondisi yang banyak terjadi perubahan di era pasca reformasi telah menambah banyak permasalahan, krisis ekonomi yang terjadi telah menyentuh dimensi politik, social budaya, hukum dan akhirnya mengkristal menjadi lahirnya suatu krisis kepercayaan, hal ini berdampak kepada sektor perkebunan.Berdasarkan data di Pemerintah Propinsi Sumatera Utara konflik pertanahan jumlahnya 2833 kasus di Sumatera Utara ${ }^{9}$. Sebagai perusahaan Badan Usaha Milik Negara disektor perkebunan, kerugian yang diderita dari sengketa tanah PT. Perkebunan Nusantara tidak sebatas pada materi saja tetapi sudah mesuk kepada kerugian immaterial, seperti semakin berkurangnya gairah dan semangat bekerja para karyawan hal ini tentunya akan berdampak buruk kepada kinerja perusahan. Pimpinan dan karyawan Kebun tersita waktunya untuk urusan penyelesaian permasalahan penggarapan tanah perkebunan.
Apabila berpedoman dengan bukti alas hak perkebunan mempunyai legalitas yang resmi dengan kata lain secara formal legalitasnya jelas terhadap tanah yang di usahai, sedangkan masyarakat petani berada di areal secara nyata menguasai menggarap tanah tetapi tidak mempunyai alas hak secara resmi berdasarkan hukum, artinya secara formal tanah masyarakat lemah bukti hukumnya.

Secara filosofi, sengketa tanah terjadi bukan soal hukum semata. Secara esensial yang terjadi adalah perbedaan konsep hak penguasaan atas tanah antara yang dianut pribumi dengan pandangan hukum positip (Eropa). Dalam pandangan pribumi, hubungan manusia dengan tanahnya ditentukan oleh intensitas de facto penggunaan atau penggarapan tanah tersebut. Makin intens pemanfaatannya, makin kukuh pula hak penguasaannya. Hal ini diperkokoh dengan keyakinan religius mereka bahwa tanah merupakan karunia Tuhan yang bisa dimiliki oleh siapa saja asal mau bekerja dan berjerih payah memanfaatkannya.

Sedang logika Eropa berbeda sebaliknya, kerja diatas tanah seberapapun luas dan beratnya tidak akan menerbitkan hak atas tanah tersebut. Konsep pemilikan tanah Eropah mempersonifikasikan kepemilikan tanahtanah sebagai pemilikan yang pada awalnya berada di tangan pemerintah. Setiap hak pemilikan dan penguasaan
9 Pemerintah Propinsi Sumatera Utara Tahun 2012, Kuliah Umum Plt. Gubernur Sumatera Utara 17 Septemer 2012 di Universitas Dharmawangsa 
tanah oleh masyarakat, ipso jure harus bermula dari pemerintah atas tanah alias domein, dalam hal ini domein pemerintah Hindia Belanda sebagai penerus hak rajaraja Jawa. Ipso facto dari kenyataan penguasaan, penempatan, pemukiman, pendudukan ataupun pengusahaan atas tanah tidak otomatis menjadi haknya seberapapun berat dan lamanya. ${ }^{10}$

Konflik yang terjadi di sektor perkebunan khususnya adalah berkaitan dengan permasalahan tanah, yang cenderung menimbulkan konflik horizontal antara perkebunan dengan masyarakat penggarap. Masalah tanah garapan di areal perkebunan dapat diklasifikasi sebagai berikut :

1. Tanah gararapan dengan dalih memperoleh hak berdasarkan bukti surat KRPT ( Kartu Reorganisasi Pemakaian Tanah ) Sumatera Timur.

2. Tanah garapan yang sudah pernah diganti rugi, tetapi pada saat ini para penggarap mengatakan belum pernah menerimanya.

3. Tanah garapan yang sudah mempunyai kekuatan hukum tetap dari Mahkamah Agung RI, tidak diakui keabsahannya oleh para penggarap.

4. Tanah garapan yang diperoleh dari Panitia Landreform yang berbeda

${ }^{10}$ Soetandyo Wignjosoebroto, dalam Abu Rohmad, Paradigma Resolusi Konflik Agraria, Walisongo Press, Semarang, 2008, hal 70-71 penafsirannya, antara penggarap dengan pikak perkebunan.

5. Tanah garapan tanpa alasan yang kuat, kecuali memanfaatkan kondisi reformasi yang disalah tafsirkan oleh para penggarap dengan cara coba-coba dan untung-untungan.

6. Tanah garapan yang berasal dari perjanjian pinjam pakai antara pihak Perkebunan dengan masyarakat, karyawan, pensiunan maupun dengan Pemerintah Daerah dan Instansiinstansi lain.

7. Tanah-tanah yang di klaim sebagai tanah hak ulayat masyarakat hukum adat.

8. Berakhir masa berlakunya hak guna usaha (HGU), masyarakat masuk keareal perkebunan dan menggarap, menguasai lahan lalu menuntut untuk mendapatkan hak atas tanah yang para penggarap kuasai dan usahai. Alasan para penggarap areal perkebunan dulunya tanah yang diusahai orang tua leluhurnya mereka dipaksa untuk meninggalkan tanahnya dengan ganti rugi tanaman dengan cara dipaksa, intimidasi.

Dengan berbagai macam latarbelakang sengketa tanah di areal hak guna usaha perkebunan tersebut yang harus dilakukan adalah menyelesaikan dan cara untuk menyelesaikannya.

\section{PERMASALAHAN :}


Bagaimana bentuk penyelesaian sengketa yang dapat menyelesaikan sengketa tanah garapan di areal hak guna usaha perkebunan?

\section{PENYELESAIAN}

SENGKETA

\section{TANAH PERKEBUNAN}

Penyelesaian adalah proses, perbuatan, cara menyelesaikan. Menyelesaikan diartikan menyudahkan, menjadikan berakhir, membereskan atau memutuskan, mengatur, memperdamaikan (perselisihan atau pertengkaran), atau mengatur sesuatu sehingga menjadi baik. ${ }^{11}$ Dean G. Fruitt dan Jeffrey Z. Rubin mengemukakan pengertian sengketa berarti ${ }^{12}$ "Persepsi mengenai perbedaan kepentingan (perceived divergence of interest), atau suatu kepercayaan bahwa aspirasi pihakpihak yang bersengketa tidak dicapai secara simultan (secara serentak)".

Penyelesaian melalui jalur hukum keputusan pengadilan tidak menjamin tanah garapan dapat dikuasai kembali oleh pihak perkebunan. Kemudian cara pendekatan keamanan terjadi bentrok fisik antara kelompok penggarap dengan karyawan-karyawan perkebunan mengakibatkan jatuh korban dan kerugian harta benda. Kegagalan penyelesaian

${ }^{11}$ Departemen Pendidikan Dan Kebudayaan, Kamus Besar Bahasa Indonesia, (Jakarta: Balai Pustaka, 1990), hal. 801.

${ }^{12}$ Salim HS, Erlies Septiana Nurbani, Penerapan Teori Hukum Pada Penelitian Tesis Dan Disertasi, PT Raja Grafindo Persada, Jakarta, 2013, hal. 136 sengketa tanah garapan di areal perkebunan disebabkan beberapa alasan, seperti ; para penggarap tidak bersedia menerima suguh hati/ganti rugi tanaman, para penggarap ingin memiliki tanah yang mereka garap, mengenai luasan areal garapan belum ada kesamaan jumlahnya antara pihak penggarap dengan perkebunan, kemudian masalah jumlah kelompok penggarap yang akan diselesaikan data kependudukannya tidak jelas. Terhadap putusan pengadilan dianggap tidak adil, memihak perkebunan dan tidak menerima keputusan Pengadilan.

Upaya penanganan sengketa pertanahan yang ditetapkan berdasarkan peraturan yang berlaku terdiri dari beberapa badan atau lembaga yang berwenang menyelesaikannya yaitu :

a. Jalur Peradilan (Litigasi), Peradilan Umum dan Peradilan Tata Usaha Negara (TUN) sebagaimana ketentuan Undang-Undang Nomor 48 Tahun 2009 tentang Kekuasaan Kehakiman

b. Jalur Non-Peradilan (Non-Litigasi), penyelesaian dapat dilakukan melalui - Mediasi, Arbitrase sebagaimana ketentuan didalam Undang-Undang Nomor 30 Tahun 2009 tentang Arbitrase dan UU No. 17 tentang RPJPN Bab III, point IV 1.5 angka 14 al. peningkatan upaya penyeleseian sengketa pertanahan 
baik melalui kewenangan

administrasi peradilan maupun alternative dispute resolution.

- Kewenangan instani pertanahan sebagaimana ketentuan Kepres 26/1988 jo. Perpres 10/2006

- Kewenangan Pemerintah Daerah sesuai Kepres 34 Tahun 2003 Tentang Kebijakan Nasional Dibidang Pertanahan.

c. Jalur Khusus, dengan cara melalui Tim Ad Hoc BPN - Polri sesuai MoU BPN dengan Polri SKB No, 10/SKB/XII/2010-B/31/XII/2010

tanggal 3 Desember 2010 tentang Sidik Sengketa bila ada indikasi pidana. $^{13}$

Sebagai instansi yang mempunyai kewenangan dalam penyelesaian sengketa di bidang pertanahan diantaranya adalah Pemerintah Daerah yaitu berdasarkan Kepetusan Presiden Nomor 34 Tahun 2003 Tentang Kebijakan Nasional Di Bidang Pertanahan, bahwa penyelesaian sengketa tanah garapan dilaksanakan oleh Pemerintah Kabupaten/Kota dan yang bersifat lintas Kabupaten/Kota dalam satu Propinsi dilaksanakan oleh Pemerintah Propinsi yang bersangkutan.

Peraturan Menteri Agraria/Kepala Badan Pertanahan Nasional No. 5 Tahun

\footnotetext{
${ }^{13}$ Badan Pertanahan Nasional Sumatera Utara, Penanganan Masalah Sengketa Dan Konflik Pertanahan, Medan, 12-10-2012
}

1999 tentang Pedoman Penyelesaian Masalah Hak Ulayat Masyarakat Hukum Adat, mengakui kekuatan kearifan tradisional dalam menguasai hak atas tanah. Pemerintah dalam bidang pertanahan membuat kebijaksanaan penguatan hak-hak kearifan tradisianal, baik perorangan maupun komunal dengan cara diberi ketegasan dan penguatan melalui pengakuan dan pendaftaran hak atas tanahnya. Peraturan ini sebagai pedoman bagi pemerintah daerah dalam melaksanakan urusan pertanahan, khususnya dalam hubungan dengan masalah hak ulayat masyarakat hukum adat yang nyata-nyata masih ada di suatu daerah tertentu. Dalam perkembangannya ternyata hak perorangan pada berbagai kawasan masyarakat adat semakin menguat. Apalagi masyarakat sendiri sudah semakin tinggi mobilitasnya, bahkan meninggalkan kawasan adatnya.Untuk mendapatkan perlindungan atas hak-haknya, maka mereka memilih mendapatkan hak berdasarkan ketentuan kebijakan agraria serta kepemilikan atas tanah serta meninggalkan ketentuan hukum adat. ${ }^{14}$

Menurut Keputusan Kepala BPN RI Nomor 34 Tahun 2007 tentang Petunjuk Teknis Penanganan dan Penyelesaian Masalah Pertanahan disebutkan bahwa masalah pertanahan

${ }^{14}$ Kusbianto, 2010, Konflik Di Perkebunan, USU Press, hal. 16 
meliputi permasalahan teknis, sengketa, konflik dan perkara pertanahan yang memerlukan pemecahan atau penyelesaian. Sedangkan sengketa pertanahan adalah perbedaan nilai, kepentingan, pendapat dan atau persepsi antara orang perorang dan atau badan hukum (privat atau publik) mengenai status penguasaan dan atau kepemilikan dan penggunaan atau pemanfaat atas bidang tanah tertentu.

Para petani penggarap diberikan hak berdasarkan Undang-undang No. 8 Tahun 1954 tentang Kartu Reorganisasi Pendaftaran Tanah dan menurut Undangundang Nomor 51 Tahun 1960 tentang Penyelesaian Pemakaian Tanah-tanah Perkebunan, Menteri Agraria harus memperhatikan rakyat pemakai tanah, kepentingan penduduk lainnya di daerah tempat letaknya perkebunan tersebut menjalankan usahanya, dengan ketentuan penyelesaian diusahakan dengan jalan musyawarah. Kegagalan penyelesaian sengketa tanah perkebunan baik yang ditempuh dengan melalui proses pengadilan (litigasi) maupun dengan cara musyawarah di luar pengadilan (nonlitigasi), ada beberapa sebab, yaitu : pertama; penyelesaian melalui pengadilan dirasakan kurang memenuhi rasa keadilan, anggapan para penggarap pengadilan berpihak kepada perkebunan. Dengan sikap pandangan penggarap yang demikian maka putusan pengadilan yang sudah berkekuatan hukum tetap tidak dapat dilaksanakan (eksekusi). Kedua; penyelesaian sengketa dengan cara pendekatan non-litigasi dengan cara pendekatan keamanan (security approach) berdampak jatuhnya korban jiwa dan harta benda, menimbulkan rasa permusuhan di kedua belah pihak semakin tajam.

Diperlukan paradigma penyelesaian sengketa tanah perkebunan dengan cara memakai paradigma pendekatan penyelesaian sengketa alternatif (alternative despute resolution). Resolusi konflik semacam ini didasarkan atas suatu falsafah bahwa konflik tidak harus diselesaikan melalui cara pandang kalah menang (win-lose solution), melainkan konflik dapat diakhiri dengan menjadikan semua pihak yang terlibat (desputans) sebagai pemenang (win-win solution) ${ }^{15}$. Penyelesaian sengketa yang diharapkan tentunya akan menghasilkan kebijakan baru dalam pertanahan yaitu suatu bentuk-bentuk penyelesaian sengketa pertanahan yang dapat mempercepat penuntasan persengketaan tanah di daerah Sumatera Utara.

Apabila berpedoman dengan bukti alas hak perkebunan mempunyai legalitas yang resmi dengan kata lain secara formal legalitasnya jelas terhadap tanah yang di usahai yaitu hak guna usaha

${ }^{15}$ Abu Rohmad, 2008, Paradigma Resolusi Konflik Agraria, Walisongo Press, Semarang, hal xix Jurnal Ilmiah "Advokasi" Vol. 06. No. 01 Maret 2018 
(HGU), sedangkan masyarakat petani berada di areal secara nyata menguasai menggarap tanah tetapi tidak mempunyai alas hak secara resmi berdasarkan hukum, artinya secara formal tanah masyarakat lemah bukti hukumnya, bukti surat yang dimiliki sebatas bukti penguasaan untuk mengerjakan tanah.

Teori Penyelesaian Sengketa (dispute settlement of theory), secara filosofis, penyelesaian sengketa merupakan upaya untuk mengembalikan hubungan para pihak yang bersengketa dalam keadaan seperti semula.Dengan pengembalian hubungan tersebut, maka mereka dapat mengadakan hubungan, baik hubungan sosial maupun hubungan hukum antara satu dengan lainnya.

Teori penyelesaian sengketa merupakan teori yang mengkaji dan menganalisis tentang: "kategori atau penggolongan sengketa atau pertentangan yang timbul dalam masyarakat, faktor penyebab terjadinya sengketa dan caracara atau strategi yang digunakan untuk mengakhiri sengketa tersebut",

Teori penyelesaian sengketa yang dikembangkan oleh Ralf Dahrendorf berorientasi kepada struktur dan institusi social. Ralf Dahrendorf berpendapat bahwa masyarakat mempunyai dua wajah, yaitu: sengketa dan .konsensus. ${ }^{16}$

${ }^{16}$ Istilah teori penyelesaian sengketa berasal dari terjemahan bahasa Inggris, yaitu dispute settlement of theory Salim HS, Erlies Septiana Nurbani, Penerapan
Simon Fisher, dkk. mengemukakan enam teori yang mengkaji dan menganalisis penyebab terjadinya sengketa ${ }^{17}$, yaitu:

1. Teori hubungan masyarakat berpendapat penyebab terjadinya sengketa adalah oleh polarisasi (kelompok yang berlawanan) yang terus terjadi, ketidakpercayaan dan permusuhan di antara kelompok yang berbeda dalam suatu masyarakat.Sasaran yang ingin dicapai teori ini adalah meningkatkan komunikasi dan saling pengertian antara kelompok-kelompok yang mengalami sengketa dan mengusahakan toleransi dan agar masyarakat lebih bisa saling menerima keragaman yang ada didalamnya.

2. Teori negosiasi prinsip menganggap bahwa penyebab terjadinya sengketa karen posisi yang tidak selaras dan perbedaan pandangan tentang sengketa oleh pihak-pihak yang bersengketa.

3. Teori identitas berasumsi (beranggapan), bahwa terjadinya sengketa disebabkan karena identitas yang terancam, yang sering berakar pada hilangnya sesuatu atau penderitaan masa lalu yang tidak diselesaikan.

Teori Hukum Pada Penelitian Tesia Dan Disertasi, Jakarta, PT. Raja Grafindo Persada, 2013) hal 135.

${ }^{17}$ Salim HS, Erlies Septiana, Penerapan Teori Hukum Pada Penelitian Tesis Dan Disertasi, PT Raja Grafindo, Jakarta, 2013, hal 144. 
4. Teori kesalahpahaman antar budaya berasumsi bahwa sengketa terjadi disebabkan ketidakcocokan dalam cara-cara berkomunikasui diantara berbagai budaya yang bersengketa.

5. Teori transformasi sengketa beasumsi bahwa sengketa terjadi disebabkan oleh masalah-masalah ketidaksetaraan dan ketidakadilan yang sebagai masalah-masalah sosial, budaya dan ekonomi.

6. Teori kebutuhan manusia berasumsi bahwa penyebab terjadinya sengketa adalah kebutuhan dasar manusia, baik fisik, mental dan sosial yang tidak terpenuhi atau dihalangi. Masalah keamanan, identitas, pengakuan, partisipasi dan otonomi yang menjadi pokok pembicaraan.

$\underline{\text { Tabel Penyelesaian Permasalahan Tanah Di PT. Perkebunan Nusantara III }}$

\begin{tabular}{|c|c|c|c|c|}
\hline \multirow[t]{2}{*}{ NO } & \multicolumn{2}{|c|}{$\begin{array}{l}\text { AREAL HGU YANG } \\
\text { BERMASALAH }\end{array}$} & \multirow{2}{*}{$\begin{array}{l}\text { PERMASAHAN } \\
\text { TANAH }\end{array}$} & \multirow[t]{2}{*}{$\begin{array}{l}\text { PENYELESAIAN YANG } \\
\text { DILAKUKAN }\end{array}$} \\
\hline & UNIT KEBUN & LUAS & & \\
\hline 1 & Gunung Pamela & 611,54 & $\begin{array}{l}\text { Ditanami palawija } \\
\text { oleh masyarakat }\end{array}$ & $\begin{array}{l}\text { Suguhati, Pengembalian } \\
\text { Sukarela dan Jalur Hukum }\end{array}$ \\
\hline 2 & Gunung Monako & 137,20 & $\begin{array}{l}\text { Ditanami tanaman } \\
\text { keras oleh } \\
\text { masyarakat }\end{array}$ & Pendekatan Untuk Suguhati \\
\hline 3 & Silau Dunia & 647,83 & $\begin{array}{l}\text { Ditanami tanaman } \\
\text { keras oleh } \\
\text { masyarakat }\end{array}$ & $\begin{array}{l}\text { Pendekatan Untuk Suguhati } \\
\text { dan Jalur Hukum }\end{array}$ \\
\hline 4 & Gunung Para & 9,14 & $\begin{array}{l}\text { Areal saat ini telah } \\
\text { berdiri rumah } \\
\text { permanen/ semi } \\
\text { permanen }\end{array}$ & Pendekatan Untuk Suguhati \\
\hline 5 & Sei Putih & 2,00 & $\begin{array}{l}\text { Ditanami ubi kayu } \\
\text { oleh masyarakat }\end{array}$ & Pendekatan Untuk Suguhati \\
\hline 6 & Pulau Mandi & 2,00 & $\begin{array}{l}\text { Areal rendahan } \\
\text { sebagai resapan air } \\
\text { digarap masyarakat }\end{array}$ & $\begin{array}{l}\text { Jalur Hukum dalam Proses } \\
\text { Peradilan }\end{array}$ \\
\hline 7 & Sarang Giting & 76,21 & $\begin{array}{l}\text { Ditanami palawija } \\
\text { oleh masyarakat }\end{array}$ & $\begin{array}{l}\text { Jalur Hukum dalam Proses } \\
\text { Peradilan }\end{array}$ \\
\hline 8 & Rambutan & 75,80 & $\begin{array}{l}\text { Ditanami tanaman } \\
\text { keras dan bangunan } \\
\text { oleh masyarakat }\end{array}$ & Pendekatan Untuk Suguhati \\
\hline 9 & Bangun & 697,88 & $\begin{array}{l}\text { Ditanami tanaman } \\
\text { keras dan bangunan } \\
\text { oleh masyarakat }\end{array}$ & $\begin{array}{l}\text { Proses Tindak Lanjut Izin } \\
\text { Pelepasan Asset }\end{array}$ \\
\hline \multirow{2}{*}{10} & \multirow{2}{*}{ Bandar Betsy } & 280,40 & $\begin{array}{l}\text { KTBR \& KOREKER } \\
\text { : Ditanami ubi kayu / } \\
\text { palawija }\end{array}$ & \multirow{2}{*}{$\begin{array}{l}\text { Jalur Hukum dalam Proses } \\
\text { Peradilan }\end{array}$} \\
\hline & & 12,00 & $\begin{array}{l}\text { Panadu / Perenngan : } \\
\text { Ditanami tanaman } \\
\text { keras }\end{array}$ & \\
\hline
\end{tabular}




\begin{tabular}{|c|c|c|l|l|}
\hline 11 & Ambalutu & 40,86 & $\begin{array}{l}\text { Ditanami kakao dan } \\
\text { kelapa sawit oleh } \\
\text { masyarakat }\end{array}$ & Pendekatan Untuk Suguhati \\
\hline 12 & Huta Padang & 2,93 & $\begin{array}{l}\text { Ditanami tanaman } \\
\text { keras oleh } \\
\text { masyarakat }\end{array}$ & Pendekatan Untuk Suguhati \\
\hline 13 & Sei Silau & 673,47 & $\begin{array}{l}\text { Ditanami tanaman } \\
\text { keras dan palawija } \\
\text { oleh masyarakat }\end{array}$ & Pendekatan Untuk Suguhati \\
\hline 14 & Merbau Selatan & 158,22 & $\begin{array}{l}\text { Diduduki/dikuasai } \\
\text { oleh masyarakat }\end{array}$ & Pendekatan Untuk Suguhati \\
\hline 15 & Rantau Prapat & 49,57 & $\begin{array}{l}\text { Ditanami tanaman } \\
\text { keras oleh } \\
\text { masyarakat }\end{array}$ & Pendekatan Untuk Suguhati \\
\hline 16 & Aek Nabara Utara & 3,60 & $\begin{array}{l}\text { Rumah Dinas dan } \\
\text { penyerobotan tanah } \\
\text { HGU }\end{array}$ & Pendekatan Untuk Suguhati \\
\hline 17 & Batang Toru & 278,93 & $\begin{array}{l}\text { Areal bermasalah } \\
\text { dengan penduduk dan } \\
\text { masyarakat }\end{array}$ & $\begin{array}{l}\text { Penyelesaian di serahkan ke } \\
\text { DATUN KEJATISU }\end{array}$ \\
\hline & Jumlah & $3.759,58$ & & \\
\hline
\end{tabular}

Sumber : Data PTPN-III Per Februari 2013

\section{TATA CARA PEMBERIAN SUGUH}

\section{HATI}

Tata cara membuat perencanaan

Suguh Hati yang dilakukan PTPN sesuai dengan UU dibentuk Tim berdasarkan SK Direksi. Tim mendata dan survey lalu membuat surat pernyataan yang didalamnya terdapat, sebagai berikut :

1. Surat Pernyataan penggarap menerima Suguh Hati

2. Letak Tanah

3. Luas Tanah

4. Jenis Tanaman dan Bangunan

Penilaian Ganti rugi Suguh Hati berupa :

1. Penentuan Harga Tanah Untuk Suguh hati, berpedoman hasil penilaian/ taksiran harga dari penilai.
2. Setiap nilai harga komponen tanaman berlaku selama 6 bulan dan setiap 2 tahun dilakukan revisi.

3. Biaya-biaya dibebankan kepada PTPN 3

\section{Tugas TIM SUGUH HATI}

1. Memanggil dan sosialisasi kepada penggarap/kelompok tani yang akan menerima Suguh Hati

2. Pendataan/inventarisasi tanah, bangunan, tanaman, dan benda lain yang ada di areal kebun objek Suguh Hati

3. Mendata status hukum tanah garapan yang akan dijadikan objek Suguh Hati

4. Meminta/menerima hasil penilaian harga tanah, bangunan, tanaman, dan 
benda-benda lainnya yang ada di tanah garapan dari penilai

5. Bermusyawarah dengan pemegang hak atas tanah garapan untuk menetapkan besarnya ganti rugi

6. Membuat surat pernyataan bersedia menerima Suguh Hati

7. Mengusulkan besarnya Suguh Hati / ganti rugi kepada Direktur / GM dalam bentuk daftar normatif untuk mendapat persetujuan

8. Membuat berita acara penyerahan dokumen atas tanah dari penggarap termasuk bangunan dan tanaman

9. Mendampingi pelaksanaan pembayaran atas tanah bangunan, tanaman dan benda-benda lainnya

10. Mendokumentasikan tiap tahap Suguh Hati, menyerahkan kepada Direksi

\section{KESIMPULAN :}

Perusahaan perkebunan PT. Perkebunan Nusantara-III dalam penyelesaian sengketa tanah yang digarap mayarakat,melalui cara musyawarah mufakat memberikan "suguh hati" berupa ganti rugi tanaman kepada para penggarap melalui Tim yang dibentu berdasarkan surat keputusan Direksi. Data yang diperoleh dijadikan dasar untuk pemberian suguh hati. Tim PTPN mendata yang berkaitan dengan permasalahan tanah garapan. Nilai ganti rugi tanaman berdasaran pedoman harga yang diperoleh dari Pemerintah yaitu Dinas Perkebunan Pemeritah Daerah setempat. Bentuk penyelesaian dengan menempuh jalan musyawarah dengan cara suguh hati lebih baik dibandingkan dengan menempuh proses hukum ke Pengadilan, alasannya lebih aman dan nyaman terjalin hubungan sosial yang baik masyarakat penggarap dengan pihak perkebunan.

\section{DAFTAR PUSTAKA}

\section{A. BUKU-BUKU}

Abu Rohmad, 2008, Paradigma Resolusi Konflik Agraria, Walisongo Press, Semarang.

Abdul Ghofur Anshori \& Sobirian Malian, 2008, Kumpulan Pidato Guru Besar Ilmu Hukum dan Filsafat, Penerbit Kreasi Total Media, Yogyakarta.

Aminuddin Ilmar, 2012, Hak Menguasai Negara Dalam Privatisasi $B U M N$, Kencana, Jakarta.

A.W.B. Simpson, 1986, History of Land Law, second edition printed in Great Britaind at The University printing House, Oxford.

Bahar, Syafroedin, 2006, "Upaya Perlindungan terhadap Eksistensi Hak-hak Tradisional Masyarakat Adat dalam Perspektif Hak Asasi Manusia”, dalam Suwarto (dkk), mengangkat Keberadan 
Hak-hak Tradisonal : Masyarakat Adat Rumpun Melayu Se- Sumatera, Pekanbaru : Unri Press.

Boedi Harsono, 1982, Hukum Agraria Indonesia, Himpunan Peraturan Peraturan Hukum Tanah, Penerbit Jambatan, Jakarta.

Eddy Pranyoto WS, 2006, Antinomi Norma Hukum Pembatalan Pemberian Hak Atas Tanah Oleh Peradilan Tata Usaha Negara Dan Badan Pertanahan Nasional, Sutomo CV, Bandung

H.L.H. Hart, 2009, Law Liberty And Morality, Hukum, Kebebasan Dan Moralitas, Genta Publishing.

Karl J. Pelzer, 1977, Toean Keboen Dan Petani Politik Kolonnial dan Perjuangan Agraria di Sumatera Timur 18631947, Penerbit Sinar Harapan, Jakarta.

Kusbianto, 2010, Konflik Di Perkebunan, USU Press.

Lawrence M. Friedman, 2009, SISTEM HUKUM: Perspektif Ilmu Sosial, Penerbit Nusa Media, Bandung.

Limbong Bernhard, 2012, Konflik Pertanahan, Penerbit Margaretha Pustaka, Jakarta

Lubis M. Solly, 2011, Penelitian Hukum, Fakultas Hukum USU.
Mahadi, 1991, Falsafah Hukum Suatu Pengantar, Penerbit Alumni Bandung.

Muhammad Yamin, Abd. Rahim Lubis, 2011, Pencabutan Hak, Pembebasan, Dan Pengadaan Tanah, Mandar Maju, Bandung.

Muhammad Tauchid, 1952, Masalah Agraria Sebagai Masalah Penghidupan Dan Kemakmuran Rakjat Indonesia, Penerbit Tjakrawala, Djakarta.

Parsudi Suparlan (Penyunting), 1993, Pembangunan yang Terpadu dan Berkesinambungan:

Keterpaduan

Pemanfaatan SumberSumber dan Potensi Masyarakat Untuk Peningkatan Dan Pengembangan Pembangunan Masyarakat Pedesaan Yang Berkesinambungan. Jakarta: Terbitan Balitbangsos Depsos RI.

Radcliffe-Brown, 1980, Struktur dan Fungsi Dalam Masyarakat

Primitif.Malaysia Kuala Lumpur: Dewan Bahasa Dan Pustaka Kementerian Pelajaran..

Roscoe Pound, 1989, Pengantar Filsafat Hukum, Penerbit Bhratara Niaga Media, Jakarta.

Rostow, W.W. 1962 The Process of Economic Growth. New York: W.W. Norton and Company Inc. 
R. Subekti, R. Tjitrosudibio, 2006, Kitab Undang-Undang Hukum Perdata, PT. Pradnya Paramita, Jakarta.

Satjipto Rahardjo, 2008, Biarkan Hukum Mengalir, Catatan Kritis tentang Pergulatan Manusia Dan Hukum,Penerbit Biku Kompas, Jakarta.

Simarmata ,Rikarda, 2006, Pengakuan Hukum Terhadap Masyarakat Adat Di Indonesia. Regional Initiative on Indigenous Peoples Rights and Development (RIPP) UNDP Redional Center in Bangkok.

Suwarto (dkk), 2006, Mengangkat Keberadaan Hak-hak Tradisional Masyarakat Adat Rumpun Melayu SeSumatera, Pekanbaru : Unri Press.

Stewart Macaulay, Lauwrence M. Friedman, John Stookey, LAW \& SOSIETY Readings on the Socisal Study of Law, W.W. Norton \& Company, New York London.

Takdir Rahmadi, 2010, Mediasi Penyelesaian Sengketa Melalui Pendekatan Mufakat, Rajagarfindo Persada,Jakarta.

\section{B. LAPORAN PENELITIAN / MAKALAH / DISERTASI}

Syafruddin Kalo, 2003, Masyarakat Dan Perkebunan: Studi
Mengenai
Pertanahan
Sengketa
Masyarakat
Antara
PTPN-II Dan PTPN-III
Di Sumatera Utara,
Disertasi, Program
Pascasarjana Universitas
Sumatera Utara, Medan.

Tan Kamello, 2006, Peralihan Hak Atas Tanah Eks Hak Guna Usaha PTPN (Persero) Sebagai Badan Usaha Milik Negara Kepada Pihak Lain, Seminar Pengalihan Hak Atas Tanah Eks Hak Guna Usaha Di Sumatera Utara: Permasalahan Dan Solusinya, Departemen Hukum Keperdataan Fakultas Hukum USU.

\section{PERATURAN}

PERUNDANG-UNDANGAN

Perundang-Undangan
Badan Usaha Milik
Negara, 2006, Koperasi
Pegawai "Prabunara"
Kementerian
Badan Usara
Negara.
Sumber Daya Alam, 2005, Fokusmedia, Bandung

\section{INTERNET}

http://docs.google.com/kumpulanj udul Disertasi2 skripsi, Thesis dan disertasi. html.

http://beritanda.com/opini/opini/op ini/5084-haruskahsengketa-lahanperkebunan-berakhirdengan-anarkis.html 